\title{
Zambia: structural adjustment or downward spiral?*
}

\author{
Philip Daniel
}

\section{Introduction}

The Zambian economy has been in severe decline for 10 years. A very large part of Zambia's difficulties is explicable by international events: most recently the recession, overlying the long-term depression in copper prices since 1974, drought since 1979, the effects of oil price increases, and, between 1965 and 1979 the consequences of the liberation struggle in Zimbabwe and the economic sanctions against the illegal regime. In 1981, the World Bank estimated that two-thirds of the fall in Zambia's per capita income between 1974 and 1978 could be explained by these external events [World Bank 1981:79]. Yet from 1964 to 1970 , the first years after Independence, Zambia experienced boom conditions, there were massive infrastructural and productive investments, and large rises in living standards for parts of the population. Why, therefore, was Zambia not better equipped to withstand the subsequent shocks? And what is now being done to encourage a revival of the Zambian economy?

\section{The Economics of Adjustment in a Mineral Exporting Economy}

Consider an economy consisting of three sectors: the mineral sector, other tradeable goods and nontradeables. ${ }^{1}$ Tradeables here refer to those goods whose prices are set on international markets, subject to transport costs, tariffs and the nominal exchange rate; while the prices of non-tradeables are determined by domestic costs and demand conditions. With full employment and immobility of capital in the short run there are two effects of a minerals boom. The first is

\footnotetext{
1 This section is a brief summary of a now widely used account of the economics of a minerals boom, see, for example. Corden and Neary (1982), or Gelb (1981)
}

* Support for the research upon which this article is based was provided by the UK Overseas Development Administration under Research Scheme R3848 Adjustment Problems of Mineral Exporting Countries'. However, the views expressed here are those of the author and do not necessarily represent the views of the ODA. termed a resource movement effect. The marginal product of labour rises in the booming sector, causing labour to move out of other sectors. This reduces non-tradeables output (while the necessary tradeable goods can be imported), so there is a rise in nontradeables prices unless spending is somehow reduced. The real effective exchange rate (the price of nontradeables relative to tradeables) therefore rises, possibly reinforcing the contractionary effect on the 'other tradeables' sector.

The second effect is called the spending effect. Increased absorption raises the price of services, and once again we have real exchange rate appreciation. Additional demand for goods from the lagging sector is met from imports. This real appreciation causes further loss of labour from the 'other tradeables' sector.

The resource movement effect may be relatively small if specialised types of labour are required in the booming sector. The extent of the spending effect depends on the marginal propensity to consume nontradeables and the availability of suitable unemployed resources. If the channel for domestic absorption of mineral rents is through government spending, the marginal propensity is likely to be high. While there may be high unemployment, the unemployed labour and resources may not be suited to rapid expansion of non-tradeables output. In Idcs the assumption of mobile unskilled labour, coupled with a 'specific factor' called capital (but perhaps including some forms of skilled labour) may well be realistic for mining.

Given wage-price flexibility, the process should reverse when the boom subsides. The subsequent productive capacity of the economy depends on the consumption and accumulation decisions made during the boom; if investments are low yielding (a common recent phenomenon in sub-Saharan Africa) then the efficient range of potential production may be narrower than would otherwise have been the case. 
Real depreciation, however, is difficult if costs in the non-tradeables sector are difficult to reduce. If real wages are inflexible, there may be long duration unemployment. Furthermore, if new industries established in potentially tradeable sectors are given substantial protection, but continue to require traded inputs when the boom subsides, adjustment will be all the more difficult. Commercial policy can alter the location of the division between tradeable and nontradeable goods. If protection permits a potentially tradeable item to be produced locally at a cost that exceeds the world market price, then, in effect, this activity is part of the non-tradeables sector in the country concerned. This analysis is applicable to much of the manufacturing industry established in Zambia in the aftermath of the mineral boom of the 1960s.

The politics of public sector management and investment allocation are central to the spending effect. Rapidly rising mineral revenues may quickly exhaust high yielding public sector projects. There will be a tendency to invest in low-yielding infrastructure projects. Public expenditure control may be relaxed, as may revenue-raising efforts outside the mineral sector. The financial intermediary role of government will support rent-seeking in the private sector, particularly if there is a prevalence of fixed factors in the non-tradeables sector (such as urban land). There will be a wage stimulus in the public sector itself, and a demonstration effect on wage costs and consumption patterns from the import of the required foreign skills. In the phase of decline of mineral revenues, there is likely to be a strong tendency to rely on controls, which in effect inhibit the adjustment process, and to support existing levels of spending through borrowing.

In the real economy of a country such as Zambia it is unlikely to be possible to move smoothly and swiftly from one production structure to another, by way of a smooth and continuous process of price adjustment. ${ }^{2}$ First, the structure will not adapt where price flexibility does not exist. Second, even with price flexibility, the structural problem may persist if price responsiveness is low, i.e. if price elasticities of supply and demand in particular markets are low. Third, certain combinations of production possibilities may not, in fact, be feasible so that new investment is required to move from one production point to another.

\section{The Evolution of the Zambian Economy}

The Zambian economy is the creation of copper exports. Cheap, subsidised food was grown on European-owned farms to feed mineworkers and public servants. African peasant farmers were

2 These points are developed in a recent paper by Pramit Chaudhuri (1984) discriminated against in their access to inputs and markets, but at the same time were prevented from responding to incentives and moving to the towns by colonial administrative controls. When Independence came in 1964, the government moved rapidly to recapture mineral rents for Zambia from the mining companies themselves, and from the former Government of the Federation of Rhodesia and Nyasaland. Controls on the movement of population were also removed. The price of copper tended to be relatively high in the middle and late 1960 s, so the ground was prepared for a classic minerals boom.

The urban share of Zambia's population rose from 20 per cent to 45 per cent over 1963 to 1980 . There was a high rate of investment in the boom years (on average 30 per cent of GDP), but the investment was mainly channelled towards protected manufacturing activities and low-yielding infrastructure, with agriculture relatively deprived of investment funds. In more recent years an increasing portion of investment was devoted to replacements.

There were very large real wage rises over 1964 to 1970; these were at first led by mineworkers, but then by public sector workers and transport workers. In other words, wage increases originated in the booming sector and the non-tradeables sector. The real earnings of citizens approximately doubled over the period. There were large increases in public sector employment. These implied a growth of relatively unproductive bureaucracy, and also a significant expansion of services to support employees in the public sector. ${ }^{3}$

The demand pressures induced by booming mineral revenues and the wage increases conceded accelerated the rate of price inflation in all non-traded activities. At the same time the trading difficulties brought about by Rhodesian UDI, and to a lesser extent, the use of protection to support import-substituting industries effectively increased the weight of 'non-traded' activities in the economy: it was no longer a simple or cheap matter to import construction services, raw materials and many types of manufactures. Imported goods with no local substitutes were liable to periodic supply interruptions; their domestic prices tended to increase during these interruptions. As a result, Zambia's overall rate of price inflation during the period from mid- 1964 to mid- 1968 was about $2 \frac{1}{2}$ times the rate of inflation in the countries from which her imports came. The real effective exchange rate for the Zambian currency appreciated by some 29 per cent over this period; in other words, adjusting for exchange rate changes, costs to Zambian producers increased on average by about 29 per cent relative to

${ }^{3}$ For further discussion see Fry (1979) and Daniel (1979). 
those facing the competing suppliers of the Zambian market. ${ }^{4}$

The shift in the cost structure of the Zambian economy was consistent with both external balance and the provision of wage jobs or self-employment opportunities for those who sought them only as long as the terms of trade (and capital inflows) allowed high and rising real levels of public spending to be sustained. It is unlikely, however, that the rise in the real effective exchange rate could have been arrested at the time by devaluation of the nominal exchange rate. The domestic policy contribution to the problem lay in the absence of an effective stabilisation strategy for domestic incomes and expenditures: mineral revenues were spent as they accrued, and the lack of an incomes policy permitted strong urban unions to achieve very large real wage increases.

Between 1965 and 1970 total public expenditure in 1970 prices grew at an average annual rate of 19.3 per cent. Between 1966 and 1973, 55 per cent of new recorded wage employment was generated in the public sector, and 40 per cent in government services alone.

In 1968 much of existing manufacturing industry was partially nationalised. In 1969 the government took a 51 per cent stake in the mining industry. At this time there was a rapid expansion of the public sector, and a shift towards managed markets for both agricultural and industrial commodities. This was very quickly to be intensified once revenues began to decline. Zambia ended the 1960s with a vastly increased urban interest to serve; public sector employees were an important element in this interest. There has been a substantial withdrawal of labour from rural areas and an associated increase in the number of female-headed households in poorer rural areas.

The balance of investment, government expenditure and employment opportunities turned progressively against rural areas in general and agriculture in particular. Relative price changes compounded the effect. The barter terms of trade between rural and urban areas has shown a steady deterioration from the point of view of the rural areas; the deterioration was estimated at 20 per cent between 1964 and 1973 [Fry 1979:74], and a further 30 per cent from 1973 to 1979 [ILO]. Thus, very roughly, the farmer had to sell twice as much output in 1979 as in 1963 to buy the same amount of urban-manufactured goods.

\footnotetext{
${ }^{4}$ Calculation of exchange rate indices is discussed by Maciejewski (1983); this index is computed as a geometrically weighted average of trading partners' currency and price indices using 1969-71 average import weights. Revised 1979-81 weights are used later (see note 5).
}

\section{The emergence of the present crisis}

Zambia approached the first oil shock and the 1974 collapse of the copper market with a social and economic structure ill-prepared for the adjustment effort that was to be required. Despite high rates of gross investment there had been no significant shift away from dependence upon the mining industry as the source of more than 90 per cent of export earnings. The investments made in infrastructure and importsubstitution industries proved to be low-yielding and to require increasing maintenance expenditures. The manufacturing sector relied upon high levels of natural and administrative protection, and on the ready availability of imported inputs. The relative prices of many of the imported inputs (notably, but not only, fuel) increased sharply during the 1970s.

The public sector had been greatly enlarged, in terms of employment, managerial responsibilities and the provision of subsidies or services. This enlargement rested upon high and rising mineral revenues, and any attempt at contraction was likely to generate resistance from public sector employees and beneficiaries. In the same vein, organised workers in urban areas had grown accustomed to regular increases in real wages already high by regional standards.

The greatly strengthened urban interest groups were likely to be the key to political stability in Zambia. Nationalist politics before Independence had been competitive and tense; there was a particularly uneasy relationship between the mineworkers' union and the ruling United National Independence Party (UNIP) [Bates 1971:126-46]. The fragile political order was bolstered by a stream of high-profile initiatives (nationalisation, Zambianisation, administrative controls and development schemes), by the encouragement of a proportionately large bureaucracy, and by rapid circulation of senior military, civil service, and parastatal personnel.

Zambian economic history in the 1970 s was dominated by efforts to protect the expanded urban interest, and consumption standards in general. Controls spread very rapidly throughout the economy: on pricing, marketing, foreign exchange and foreign trade. At the same time subsidies were maintained and increased on a wide range of items. The principal subsidies were intended to lower the cost of food to the urban consumer; but subsidies also extended, for example, to some classes of agricultural inputs, and to interest rates on credit to modern industry. In the closing years of the 1970s there was very substantial borrowing by the government and the parastatal sector to maintain public consumption levels.

Meanwhile Zambia was plagued by external problems. The price of copper was depressed in 1972, 
temporarily reached new peaks in 1973-74, and then collapsed. By 1980 the income terms of trade had deteriorated to 37 per cent of the 1970 level. The aftermath of Rhodesian UDI in 1965 was prolonged beyond all expectations: Zambia bore the brunt of efforts to impose economic sanctions on the illegal regime and was forced to invest substantially in the redirection of its transport routes. From about 1974 Zambia suffered from the intensification of the armed struggle in Rhodesia, from civil war in Angola, and from chronic instability in the Shaba province of neighbouring Zaire. On top of all these difficulties came natural and ecological difficulties. From 1979, Zambia, in common with other countries in the region, began to suffer unusual degrees of drought. Then in the 1980s it became clear that the mining industry itself would not last for ever; realistic appraisals of the possibility of depletion of the Copperbelt ore bodies began to appear. Total copper production began a steady decline somewhat earlier, and unit costs increased precisely when prices were at their weakest.

The maintenance of consumption relative to investment meant that there were huge net national dissavings. Net national savings in real terms were negative in 1983 and had, in effect, fallen by 112 per cent from the $1970 \mathrm{~s}$ level. The core of the problem lay with central government: the government current deficit reached 11 per cent of gross domestic income in 1981 and 12.5 per cent in 1982.

Underpinning the maintenance of consumption levels was a significant rise in the share of compensation of employees in net domestic factor income: the share rose from approximately 51 per cent in 1970 to nearly 62 per cent in 1983, indicating that profits and selfemployment incomes bore a proportionately greater share of the external squeeze on Zambia's economy while wage incomes were protected.

\section{External and Internal Imbalances}

Inflationary pressures remained consistently strong over the 1970s: Zambia's average rate of inflation from 1973 to 1982 exceeded the average for her trading partners by some 28 per cent (using official consumer price indices). The rate of inflation appears to have been directly affected by the availability of foreign exchange for imports; when, in 1979 and 1980, copper and cobalt prices temporarily improved, Zambia's rate of inflation decelerated. Zambia's competitive position was thus liable to rapid deterioration. Despite two devaluations of the kwacha, Zambia's real effective exchange rate in 1980 was only slightly below the level reached in 1970 at the end of the minerals boom. Further sharp real appreciation occurred up to the end of 1982. These calculations probably understate the full extent of the problem because of the pervasiveness of official price controls.

External payments arrears (the 'pipeline') began to accumulate in 1975. They accumulated in every year thereafter except 1979 , totalling K $702.6 \mathrm{mn}$ by the end of 1983 [Bank of Zambia 1983:52]. The other element of debt which has risen very rapidly is that to the IMF. By the end of 1984 outstanding debt to the Fund was SDR $712 \mathrm{mn}$ or about 28 per cent of GDP. Of the total debt outstanding at the end of December 1983 of $\$ 2,638 \mathrm{mn}$, the different categories of debt accounted for the following amounts [World Bank 1984:56]:

$\begin{array}{lr} & \$ m n \\ \text { Suppliers' credits } & 275.2 \\ \text { Private finance } & 328.8 \\ \text { Multilateral official } & 530.5 \\ \text { Bilateral official } & 1503.5\end{array}$

The total converts to $\mathrm{K} 3,985.5 \mathrm{mn}$, to which we can add the outstanding arrears and the IMF debt of SDR $635.7 \mathrm{mn}$ at the end of 1983 . This would give a total debt outstanding at the end of 1983 of about K 5.5 bn or 130 per cent of GDP.

The debt service obligations arising from these outstanding amounts are of course enormous: in 1984 servicing the IMF alone was to cost $\mathrm{K} 247 \mathrm{mn}$, total debt service (unrescheduled) would have been about $\mathrm{K} 1.4 \mathrm{bn}$. With FOB exports estimated at K $1433.0 \mathrm{mn}$, debt service obligations, unrescheduled, account for virtually 100 per cent of export earnings, while the obligation to clear the pipeline increases notional debt service by a further 60 per cent.

The ILO/JASPA mission of 1980 assembled disturbing evidence of the effects of Zambia's decline upon the poorest groups [ILO/JASPA 1981]. It identified declining standards of nutrition, shortages of basic supplies in the education and health systems, and lack of investment in the kinds of assets, inputs or technologies which could help low-income households in areas away from the line of rail. It also pointed to the relative protection of the urban interest by means of food subsidies, expanding public sector employment and periodic money wage increases.

The combination of general economic deterioration, foreign exchange shortage and controls has led to widespread price distortions, illegal transactions and smuggling. Such transactions, however, have not reached the levels experienced in some neighbouring economies. Capacity utilisation in the manufacturing sector is probably as low as 30 per cent, principally because of the constraint upon imported inputs. The growth of agricultural production has remained sluggish. Maize has been persistently vulnerable to 
drought, whatever the price position; the peak of 750,000 tonnes marketed production in 1976 has not been repeated, though price developments now make this possible if weather conditions are favourable. Production of animal products has risen, but that of other agricultural commodities has been stagnant. In general, the economy exhibits all the symptoms of severe deterioration: there has been slow physical output growth, and an absolute reduction in some sectors. Infrastructure is deteriorating at a rapid rate, maintenance has not been carried out, and by 1982 a severe risk had emerged of the kind of downward spiral of activity experienced in some other subSaharan countries.

\section{The Reform Programme}

The programme begun in December 1982 is comprehensive and strongly supported by the international financial institutions. Zambia has taken action on the exchange rate, agricultural producer prices, industrial output prices and the price control system, incentives to exporters including special provisions for retention of foreign exchange from nontraditional exports, measures to tighten the budget and budgetary management, wage policy measures and reform of the import tariff. External support has been secured for a $\$ 300 \mathrm{mn}$ rehabilitation programme in the mining industry, and new taxes have been imposed to restore a revenue contribution from mining.

The prospects for any substantial recovery of mineral export earnings are poor; the price of copper is expected to remain depressed for the rest of the decade, and Zambia's output levels are in any case tending to fall. The economy faces the basic problem of how to prevent the incomes of all social groups from falling. Within the general problem, there are distributional implications of any recovery. At present an economic recovery appears to mean redistribution of income from wage and salary earners, subsidy recipients and rent seekers, to profit recipients, farmers in general, and foreign creditors.

The necessary structural change in Zambia means shifting the economy from one which is mineral dependent, with a large public sector, managed markets, and extremely open (in terms of ratio of trade to GDP) towards a more diversified, more private sector-dominated economy, with freer markets, but probably less open in terms of the importance of foreign trade if self-sufficiency in basic foods is achieved and if the manufacturing sector raises its proportionate use of local inputs. These structural changes have to be achieved while the economy remains a net exporter of capital for at least five years, as it pays off its accumulated burden of foreign debt.
The principal stabilisation objective is to raise the savings rate to the point where there is an excess of national saving over investment, and a counterpart balance of payments surplus on current account. Unless this is done (and assuming that no massive increase in grant aid is available) Zambia cannot be a net exporter of capital and thus cannot service her debt. Since negative saving is overwhelmingly a public sector problem, a dramatic closure of the fiscal deficit is required.

There is extreme difficulty in closing the deficit from the revenue side, however, since more than four-fifths of tax revenue is directly related to the level of domestic economic activity, and the remainder to mineral output - tax rates have already been raised sharply to compensate for the fall in mineral revenues since 1974. The foreign exchange shortage in itself prevents the increase in activity levels that is needed to raise government savings. The government has therefore tried to achieve sharp increases in mineral revenues, despite the continuing depression in world metal prices: a new export levy has been imposed, against which past and present losses cannot be offset; substantial rehabilitation and maintenance programmes in the mines are being funded; the mines are permitted to retain 35 per cent of their foreign currency earnings to purchase imported inputs; and the kwacha has been progressively devalued in nominal terms to an extent sufficient to allow Zambia Consolidated Copper Mines (ZCCM) to show an operating profit in local currency before the export levy is deducted (about half ZCCM's total costs are believed to be foreign currency expenditures). The channelling of investible funds and foreign currency retentions to ZCCM in the short-run inevitably reduces the resources available for diversification. Despite the poor long run prospects for Zambia's mining industry, the judgement has been made that this is the best route to short-run stabilisation, without which medium-term diversification has little chance.

On the expenditure side, the problem is if anything still more acute. In 1982 debt service alone was the equivalent of 27 per cent of total revenue and grants; the kwacha cost of foreign debt service has since increased sharply with the large nominal depreciation of the kwacha. Subsidies (at 33 per cent of receipts, or 19 per cent of outlays in 1982) have been important to the maintenance of urban living standards, as have wages and salaries ( 53 per cent of receipts, 30 per cent of outlays); direct cuts in these items are necessary for success in adjustment, though, if pressed too far too quickly, they could jeopardise the political basis of the reform programme. Defence expenditures have inevitably been high, though they are not publicly identified. The government has a strong political commitment to the maintenance of public sector 
employment, and of free education and health services. At the same time, there is wide agreement that current non-wage spending on productive sectors has been too low and needs to be increased if agricultural and industrial output is to be increased.

The conflicting pressures on the expenditure side of the budget make it hard to achieve the restructuring that appears to be needed: reduction in the range of government activities, a switch from subsidies and transfers to productive recurrent expenditures, and probably a reduction in government employment. It is simpler in the short-run to seek to control the total nominal level of government spending by economies across the board, relying upon the effects of rising inflation to reduce real spending. If the combined impact of such an expenditure strategy and the revenue strategy described is a marked reduction in the deficit as a share of GDP, the incentive to restructure the budget is likely to be reduced. The relative success of 1983 and 1984 may well have produced this perverse result: the pressure to restore spending levels in a largely unreformed budget structure seems to have broken through in a 1985 budget which promises a much increased fiscal deficit.

\section{Production Structure Adjustment}

Adjustment in the production structure will contribute to the short-run stabilisation effort, but is even more fundamental to the longer term effort to restore growth of incomes for Zambians. In sectoral terms, structural adjustment means raising the share of agriculture in GDP, and especially in investment and exports; it implies a reduction in the share of mining even though the decline of mining is intended to slow down. In economic terms (recalling the framework set out earlier in this article), long-run structural adjustment has three interrelated facets. First, the cost structure of the Zambian economy has to be shifted downwards, both cancelling out the rise that occurred in the minerals boom of the 1960 s and making internal and external balance compatible with the outlook for the terms of trade and capital inflows. Cost reduction requires a sharp increase in the rate of capacity utilisation, and an associated reduction in labour cost per unit of output. Second, tradeables production has to expand relative to non-tradeables (which is not the same as a move to a more open economy since it includes efficient import substitution); reduction in costs will make a major contribution to this shift, but so too will the easing of import controls and progress towards a more uniform external tariff. Third, and perhaps most immediate, part of the shift to tradeables production involves making existing capacity geared to the domestic market competitive in export markets.

At present these tasks are being approached by very large nominal price adjustments: exchange rate depreciation, decontrol of industrial output prices, and increases in the administered producer prices for agricultural products. During 1983 and the first part of 1984 there were also wage controls; these have now been abandoned, with implications which are considered below.

Great weight is being placed upon the efficacy of nominal depreciation of the kwacha. With other nominal variables unchanged (especially government spending and wage levels), exchange rate depreciation contributes in differing degrees to five objectives. It should increase the profitability of mining and thus raise government revenue; it should ease the pressure of demand on the exchange control system; it should reduce the real value of government spending in proportion to its import content; it should raise the kwacha profitability of exporting (insofar as kwacha export prices are fixed by the exchange rate, but prices on domestic markets are free to vary with supply and demand conditions); and it should raise the price of tradeables relative to labour, thus inducing expanded production of both exports and import-substitutes.

These responses are crucially dependent on two assumptions: first, that other nominal variables do not change, or at least change by less than the amount of the depreciation; and, second, that the complementary inputs needed to allow producers to respond to the price changes are in fact available. There are considerable difficulties with both these assumptions. The objective at which depreciation appears to be principally aimed at present - and with a high degree of success - is that of improving the fiscal position by raising the profitability of mining. In other words, the exchange rate is being used as an instrument of fiscal policy, in order to affect external demand by reducing absorption rather than by switching. Depreciation certainly has relative price effects in present circumstances, but these are probably less significant (in terms of BOP impact) than its fiscal effects, and other pricing measures (decontrol, producer price increases and wage restraint) appear to have stronger relative price effects.

In January 1983 there was an immediate devaluation of 20 per cent against the SDR. In July 1983 the kwacha was delinked from the SDR and pegged to an unannounced basket of currencies; the nominal rate for the kwacha against the basket has since been progressively depreciated without the embarrassment of announcing a large discrete devaluation.

Against an import-weighted basket of currencies the kwacha depreciated in nominal terms by 43 per cent from the fourth quarter of 1982 to the third quarter of 
1984. ${ }^{5}$ Depreciation has subsequently continued, Using the conventional IMF inflation adjustment with consumer price indices, the real depreciation over the same period was 26 per cent. The January 1983 devaluation approximately restored the position as at the end of 1980, while the subsequent 'crawl' has eliminated more than the equivalent of the real appreciation which occurred in the 1960s. Since Zambia's external position has deteriorated so much in the intervening years, the kwacha is of course still a long way from an 'equilibrium' rate.

In the Zambian case however the conventional calculation of a real effective exchange rate is not altogether applicable since it presumes an open economy without trade controls, and a distinction between non-tradeable and tradeable sectors which is not excessively distorted by commercial policy. The real exchange rate index can therefore be used only as a rough guide to the economy's relative cost position.

For these reasons it is also important to look at the effect of the nominal exchange rate itself: it will affect the extent of smuggling of goods, and parallel market dealings in foreign exchange; it will also affect the short run profitability of exporters. If the returns to non-traditional exporters are effectively fixed in kwacha terms by the exchange rate, whereas their prices in the domestic market are to some extent free to vary, then in conditions of exchange control there will be a bias in favour of production for the home market. Nominal exchange rate depreciation can correct this bias even if the real effective exchange rate does not depreciate [Krueger, 1983:174-175].

\section{Domestic Price Evolution}

In December 1982, the prices of most commodities were decontrolled (the exceptions were maize meal, wheat products and candles). As expected, this measure has produced a significant increase in consumer price inflation (in combination with the effects of devaluation and removal of subsidies). In the year 1983 the official low-income urban consumer price index rose by 23.5 per cent, compared with 14.2 per cent in 1982. On the basis of figures up to September 1984, the official rate for 1984 appeared likely to drop below 20 per cent, suggesting that the

\footnotetext{
5 The basket was constructed by the present writer for this article from IMF Direction of Trade data. The Zambian kwacha was pegged to the SDR until July 1983. The basket used here comprises the following weights (1979-81 weighted average import distribution):

$\begin{array}{ll}\text { US dollar } & 0.4173 \\ \text { UK pound } & 0.3130 \\ \text { Deutschemark } & 0.1078 \\ \text { South African Rand } & 0.0933 \\ \text { Japanese Yen } & 0.0686\end{array}$
}

main inflationary impact of decontrol occurred in 1983. Nevertheless, apart from queries about the reliability of the index, the extent of genuine marketrelated pricing is open to doubt because of the dominance of parastatal enterprises in the production and distribution of consumer goods. (Zambia has about 138 central government-owned non-financial public enterprises, and another 165 minor ones owned by local government.) Pricing by parastatal enterprises with a significant monopoly position in their markets is likely to be subject to explicit or implicit governmental restraints.

Agricultural producer prices have been substantially raised as part of the reform programme. Nevertheless, the effect of these changes on the purchasing power of farmers has not been as dramatic as the nominal increases might suggest. The most positive case is that of maize, where the producer price rose by 38 per cent in real terms between the 1973/74 and 1983/84 seasons. The overall effect has been to produce a strong relative price shift in favour of maize; this is in line with national objectives of maize self-sufficiency, but is not in line with the objective of improving agricultural production in those drought-prone (and relatively poor) areas where production of coarse grains such as sorghum and millet might be favoured. In cash crops, Zambia has reversed international price trends for tobacco, but has improved domestic groundnut prices relative to those prevailing internationally. The groundnut price change however has still not prevented extensive smuggling of the groundnut crop.

During 1983 an effective ceiling of 10 per cent on money wage increases was maintained as part of the conditions to be observed in drawing down the IMF stand-by credit. No up-to-date figures on earnings movements are available, but it seems likely that wages were sufficiently restrained to permit an increase in the ratio of kwacha output prices to labour costs. Other intermediate input prices, however, are likely to have increased proportionately with output prices as a result of devaluation and decontrol. The very sharp real cut in public spending in 1983 (and the smaller real cut in 1984) and the associated narrowing of the fiscal deficit eased both inflationary pressure - below the levels it would otherwise have attained - and the government's claim on available foreign exchange. Accordingly, it is likely that the pricing measures taken in the first two years of Zambia's adjustment programme have met with some successes in raising the potential profitability of exporting activities, and tradeables production in general.

ln October 1984, however, the government announced that the 10 per cent wage ceiling was not to be renewed; instead there would be a limited return to collective 
bargaining'. It is understood that the new IMF Standby agreed in July 1984 contained no condition about wage regulation; from which it must be inferred that the IMF (and perhaps the government) believes that restraint on aggregate demand is sufficient to curtail wage concessions by employers, while fiscal restraint will restrain government pay awards. In view of the strength of Zambia's labour movement and its past record, the wisdom of abandoning a central wage guideline is at least questionable. As we have seen, the 1985 budget appears to be less deflationary than the previous two. For both fiscal and labour market reasons, therefore, renewed inflationary pressure seems possible for the current year, threatening the important relative price changes recently achieved.

\section{Price Changes, Input Constraints and Output Responses}

Far more serious in the short-run, however, is lack of complementary inputs to enable producers to respond to price changes. For some years, capacity utilisation in manufacturing has been informally estimated at between 30 and 50 per cent. Agricultural activities are persistently affected by shortages of fertiliser, equipment, spare parts, fuel and - if crops are produced, collected and prices actually paid - of consumer goods to meet farmers' own needs. Symptoms of the lack of foreign exchange appear in basic physical and social infrastructure throughout the country. Much of the 1984 maize crop suffered collection delays and spoilage because of shortages of trucks, tyres and fuel. In the absence of a recovery of import capacity (by increased export earnings, debt relief or more aid), a rise in tradeables output depends upon the foreign exchange allocation decisions that are taken, and on the extent to which import-intensive production and distribution systems can be replaced by those which are not. These are in large part political matters involving public allocation systems (importlicence, foreign exchange and credit allocation), and the structure of the public sector (can maize collection by cooperative unions and NAMBOARD be replaced by allowing producers to transport their own crop direct to private millers?). In these areas much less has been achieved - a situation that has possibly been obscured by the scale and high profile of nominal price changes.

In order to encourage 'non-traditional exports' (i.e. exports other than copper and cobalt) a foreign exchange retention scheme analogous to that operated for the mines, but at a higher rate of 50 per cent of gross export proceeds, was introduced.

The opportunity to earn foreign exchange for use within the enterprise quickly encouraged local firms to create at least an exportable margin from existing capacity. In 1983 non-metal exports registered by the Bank of Zambia were five times higher than in $1982-$ though still at the relatively low level of $K 77 \mathrm{mn}$. Overall foreign exchange allocations to manufacturing continued to decline in real terms, and allocations to agriculture have been widely viewed as inadequate. The government has been forced to allocate foreign exchange for emergency food imports, and gives priority to inputs for essential social services. The retention schemes are therefore helpful only to those industries which can export successfully at their initial levels of capacity utilisation. Without the availability of additional foreign exchange for maintenance, rehabilitation and new investment, it is difficult to envisage more than a modest further rise in nontraditional exports in response to the new incentives.

The IMF stand-by credit agreed in July 1984 relied on some very optimistic assumptions about copper production and prices, maize and fertiliser output, and the expansion of non-traditional exports. The optimism is necessary to underpin the repayments consequent on Zambia's borrowings: from 1986 Zambia's repayments to the IMF will exceed its drawings, and after 1987 there will be no further drawings at all from the IMF.

Disbursement of the IMF credit early in 1985 reportedly halted after only SDR $80 \mathrm{mn}$ of the SDR $225 \mathrm{mn}$ has been drawn. The Fund and the Zambian Government were in disagreement over subsidies, the pace of depreciation, and measures to clear the payments pipeline. The attempt to accelerate nominal price adjustments thus jeopardises the momentum of reform.

\section{Conclusions}

The copper revenue boom of the 1960s was managed without a stabilisation strategy: non-tradeables output expanded, the real exchange rate appreciated, and non-mineral tradeables production was hampered.

The Zambian reform programme represents a determined attempt to remove some of the obstacles in the path of adjustment. It is suggested, however, that the present reliance of the programme on nominal price adjustments, while initially helpful, needs to be shifted towards more direct measures to cope with Zambia's high cost structure and institutional problems: measures to reduce public expenditure obligations, improve agricultural marketing and raise capacity utilisation.

Finally, it is difficult to see that the programme can be sustained without some new net foreign exchange injection, either in debt relief, or in aid. Low capacity utilisation is itself a major cause of fiscal and cost- 
competitiveness problems, and it is caused by shortages of foreign exchange. The programme in Zambia now has sufficient momentum that renewed foreign exchange inflows need not deflect the government from its course.

\section{References}

Bank of Zambia, 1983, Annual Report 1983, Lusaka

Bates, Robert H., 1971, Unions, Parties and Political Development: A Study of Mineworkers in Zambia, Yale, U. P.

Chaudhuri, P., 1984, 'Structural problems and development policy', University of Sussex, mimeo (presented at the ESRC Development Economics Research Seminar, University of Warwick, November)

Corden, W. M. and P. J. Neary, 1982, 'Booming sector and de-industrialisation in a smatl open economy', Economic Journal, 92, December, pp825-48
Daniel, Philip, 1979, Africanisation, Nationalisation and Inequality: Mining Labour and the Copperbelt in Zambian Development, CUP

Fry, James, 1979, Employment and Income Distribution in the African Economy, Croom Helm, London

Gelb, Alan H., 1981, 'Capital-importing oil exporters: adjustment issues and policy choices', World Bank Staff Working Paper No 475, August

ILO/JASPA, 1981, Basic Needs in an Economy under Pressure - Report of a Basic Needs Mission to Zambia, Addis Ababa

Krueger, Anne O., 1983, Exchange Rate Determination, CUP

Maciejewski, E. B., 1983, "Real" effective exchange rate indices: a re-examination of the major conceptual and methodological issues', IMF Staff Papers, vol 30 no 3, September, pp491-541

World Bank, 1981, World Development Report 1981 -1984. World Debt Tables: Second Supplement, Washington DC 